\title{
Management of Vineyard Variability: A Simple and Effective Alternative to the Precision Viticulture.
} \author{
AlexeySapsay ${ }^{1}$, José Luis Aleixandre-Tudó ${ }^{1,3}$, Josep LLuis Pérez ${ }^{2}$, José LuisAleixandre ${ }^{1}$ \\ ${ }^{1}$ Institute of Food Engineering for Development (IIAD), Politechnic University of Valencia, Spain \\ ${ }^{2}$ Mas Martinet Assessorament, Catalonia, Spain \\ ${ }^{3}$ Departament of Viticulture and Enology, Stellenbosch University, South Africa
}

\begin{abstract}
Each vine within a parcel has a specific growing force and depends on several factors such as type of rootstock, soil properties, water and nutritional status of the plant. The quality of grapes produced by the vines of different vigor is heterogeneous (if treated conventionally) which creates a general loss of quality of the harvest. Thus, the management of the heterogeneity of the vigor within a plot represents a particular interest in increasing the quality of the harvest and maximizing the qualitative potential of the parcel. The first year the plot is left without trimming so that each vine could express $100 \%$ of its vigor. In winter, the vine is pruned and the wood is then weighted for each plant. This weight is divided by $50 \mathrm{~g}$ (the weight of a stem of $1 \mathrm{~m}$. $20 \mathrm{~cm}$ ) to avoid trimming during the growing period and to have a possibility to repeat the procedure the following year. The number obtained is the load that must be left for the vine for the current year. The load is then corrected by green pruning for each vine. All plants are divided into four groups of different vigor in order to compare the quality of grapes and wine from each group. After two years of using the technique of dividing vegetative mass on a specific number of shoots per vine, it was found that the wines made of grapes from vines of four groups studied are only slightly different at the analytical and organoleptic level. The average length of stems has been brought to the same level for all the 4 groups of vigor.
\end{abstract}

Keyword: vineyard variability, precision viticulture, vigor management, pruning, vine balance.

\section{INTRODUCTION}

Within vineyard variability is an issue that is known surely by every vine-grower. Every autumn going through the plot and trying to determine the date of the harvest, the viticulturist is often confused by the heterogeneity of the taste of berries: some being nearly green and others over matured already. Some authors (Bramley and Hamilton, 2007; Cortell and al., 2008) relate these differences with the variation of the vine vigor within a plot. The vines of low vigor are considered to produce the wine of better quality. And it actually fits the common picture prevalent among professionals working with the wine about the quality of grapes: more the vigor is, the higher is the production and the lower is the quality. Surely, for most cases these statements are true and they can help to understand as the matter of fact to what extend the variability of the parcel in terms of vigor is important for the quality of the production. The more is the variability (the more the quality of the production is averaged).

In practice, every plot even if very little is heterogeneous due to the soil variations that can be met at distances as little as few meters (Marguerit, 2006; Hubbard and Rubin 2004; Miles, 2005). Therefore the understanding of real reasons of such variability and of the ways for its management represents in reality the key advantage for winemakers in the struggle for the higher quality of the production.

Namely this study was designed with the aim to find the real cause of different performance of vines with different vigor and to verify whether the new technique developed by Josep Lluis Perez from Mas Martinet Assessoraments is able to reduce within vineyard variability and to bring the quality of grapes originating from vigorous vines to the same level as the grapes from the vines of low vigor.

The subject of the study of vine vigor and subsequently of within vineyard variability was born of a simple practical necessity. In the early 90s the company Mas Martinet Assessoraments began its experiments on the construction of new types of ecological terraces which reduce the visual impact on the landscape. The ability to retain water and the rate of organic matter in the soil of these new buildings was higher compared to traditional terraces and could be traduced by the excessive vigor often considered detrimental to grape quality (Perez, 2007). 
The experience of the estate in working with old vines showed that the best raw material for high-end wines had the following characteristics: small berries and loose grape cluster. A simple test of distribution of probable content of alcohol with loose cluster from low vigorous old vines and a compact cluster from young vigorous vine gave an idea of the probable reasons of higher grape quality from old vines (Singleton, 1966).

The compact cluster with the same average of probable content of alcohol that the loose cluster contains a part of the berries under and over-matured that can potentially be a source of loss of quality. On the one hand, not sufficiently matured berries can communicate vegetal character to the wine and on the other, over-matured berries are put under the risk of black rot attack.

Having understood the ideal characteristics for its raw material, the company Mas Martinet Assessoraments had to develop a strategy for managing the terraced plots in order to achieve these objectives. Two ways were chosen for developing the strategy of management of quality: the observation and consideration of variables influencing the behavior of the vine. By means of observation, it was noted that the rather loose clusters are produced by shoots of the length of 90-130 $\mathrm{cm}$, while the compact clusters originate mostly from excessively long shoots that tend to fall and often are cut. These findings are actually in agreements with the results of investigations of several authors (Archer and Hunter, 2003; Landolt, 2011).

However, as noted above, the plants in a plot hold a different vigor and if they are treated uniformly, the length of the shoots cannot be the same promoting thus heterogeneity and qualitative loss of production. Thereby, the only way to reduce variability and to achieve the same length of all the shoots within a plot is to treat every plant individually and accordingly to its vigor. In practice this is feasible through the mechanism of compensation of the plant that help the vine to adapt to environmental changes and to different levels of load (Hunter, 2000; Stein, 2011; Rousseau, 2007 ; Landolt, 2011).

Namely this mechanism has been considered as a likely source of effective management of within vineyard variability. It is known that increasing the load of the vine, the stems get thinner and shorter (Rousseau, 2007). However, depending on what the particular load should be attributed to each vine?. The team of Mas Martinet Assessoraments has seen that ideal length of a shoot for their trellising system is about $1,2 \mathrm{~m}$ which is thin enough and has a leaf surface of $0,24 \mathrm{~m} 2$ which is enough for ripening a grape cluster of $250 \mathrm{~g}$. The weight of this shoot in summer is $50 \mathrm{~g}$ (for Grenache Noir), thus in order to make all vine produce such shoot, their vigor (wood pruned in winter) should be divided by $50 \mathrm{~g}$ (see the formula below).

$$
\text { Nshoots }=\mathrm{Wpw} / 50
$$

Nshoots - number of shoots that should be developed on the arms of the plant

Wpw - weight of the wood pruned

50 - the weight of the shoot of 1,2 m length (valid for Grenache Noir)

The main objective of this study is to validate the new technique for spatial distribution of vine vigor that would reduce the heterogeneity of the quality of grapes and wine originating from the vines of different vigor within a plot.

\section{Materials AND MeThods}

The study site is called Bancal Gran and fitted ideally the objectives of the study thanks to its positioning on the plane, Lyre trellising system (able to accommodate high bud load) and high within vineyard variability. Total surface is $0,43 \mathrm{Ha}$ and number of plants treated 1410 . In order to avoid inter-annual variation and additional factors that could influence the result all the operations were standardized for each year of the study.

\subsection{The Treatment}

All the vines in the study plot are pruned in February, the wood of each plant is put next to it and then weighed with the pocket scale Baxtran KRN5. The weight is then divided by 50 (according to the formula proposed by Mas Martinet) and the value obtained is marked on the label attached on the trunk of each vine. This value represents the number of buds that has to be left on the plant. Ideally, on a meter of arm there should be 10-14 spurs with one single bud each. If the arms of the vine could 
not provide enough space, two buds are left on the spur, but the arms are marked with a tag in order to extend them next year by folding one or two canes and tying them on the conduction wire. Conversely, if the arms of the plant are too long for the load assigned, they are shortened.

After budburst, unwanted shoots are removed during 3 green pruning sessions (in mid-May, late May and early June) so that eventually the number of shoots developed strictly corresponds to the number of buds left.

All plants were then divided into four groups according to their vigor (pruning weight). The principles of division into groups were developed during the first year of study. The groups are:

$\mathrm{I}$ - Vines of low vigor and the pruning weight of 100-349 $\mathrm{g}$

II - Vines of low to medium vigor and the pruning weight of 350-649 $\mathrm{g}$

III - Vines of medium to high vigor and the pruning weight of 650-999 $\mathrm{g}$

IV - Vines of high vigor and the pruning weight of more than $1000 \mathrm{~g}$

The distribution on the study plot of plants of different vigor is shown on the map (Figure1)

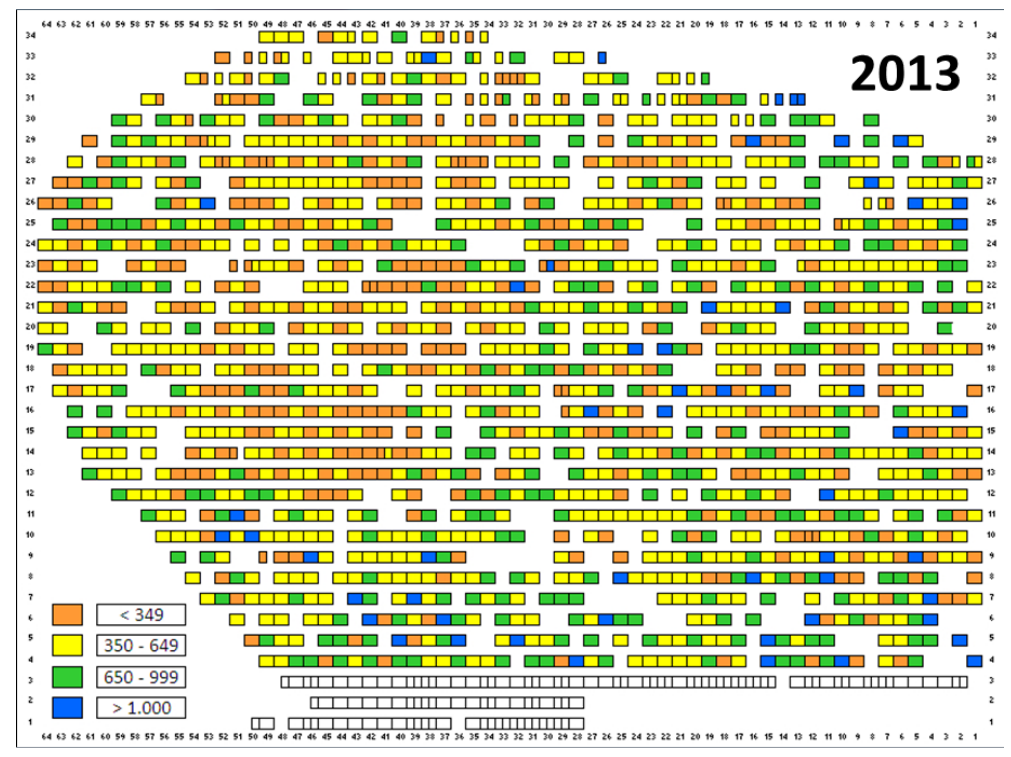

Figure1. The visualization of within vineyard variability of vigor (all plants divided into4 groups of vigor (in g.)) on the experimental plot Bancal Gran.

As we can see, the plot is highly heterogeneous; it's difficult to distinguish zones of vigor and to differentiate the harvest as suggested by Precision Viticulture. In this study we tried to challenge this inconvenient and to manage the variability of the quality of grapes by the technique Mas Martinet Assessoraments.

\subsection{Sampling of Vines for Monitoring the Growth}

Before the start of the study the plot was believed to be planted only with Grenache Noir, but the presence of other varieties was revealed later (Stein, 2011). Furthermore, the Grenache Noir finally represented only $41 \%$ of all vines planted on the experimental plot, the rest was Grenache Peluda. During the first year of the study the monitoring of the growth of these two varieties has been made and significant differences in the dynamics of growth of shoots were found (Stein, 2011). During the 2012 growing season the growth was not followed and during the 2013 season the measures were focused on a single variety (Grenache Noir). It was decided that each group of vigor will be represented by 18 plants and four shoots on each plant were selected and marked with a ribbon. The shoots on one arm were preferred in order to take into account the possibility of acrotony. A total of 78 plants (approximately $14 \%$ of the total amount of Grenache Noir on the plot) participated in growth monitoring. The length of the selected shoots was measured every week from 5th week after bud break and till the stop of the growth. 


\subsection{Winemaking}

The fermentation was performed in $500 \mathrm{~L}$ stainless steel tanks with a cooling system. Inside the tank was installed a cylindrical grid welded from one side, the other opens. The destemmed and crushed grapes are loaded into the tank through the grid so that the skin stays in its interior. The grid is then closed and submerged into the liquid in order to avoid the formation of a skin cap. A separator reducing the formation of foam is placed between the gate and the floating cap. The fermentation is carried out by indigenous yeasts, with no added sulfites and without the presence of oxygen. Once fermentation is completed, the wine is transferred directly into the barrel for malolactic fermentation and subsequent aging.

The wines obtained from the vines of 4 groups of vigor were analyzed in the analytical laboratory on alcohol content, titratable acidity, $\mathrm{pH}$, phenolic compounds content, anthocyanin content, color intensity and tannin content. Organoleptic analysis and comparing test were performed in Vitec Research Center (Priorat, Spain) by the panel of certified judges.

\subsection{Statistical Analysis}

The analysis of variance ANOVA was performed to estimate the differences between the groups studied in terms of growth of shoots during the growing season. The ANOVA and Tukey tests were made for the analysis of sensory differences between the wines of four groups of vigor.

\section{RESULTS AND DISCUSSION}

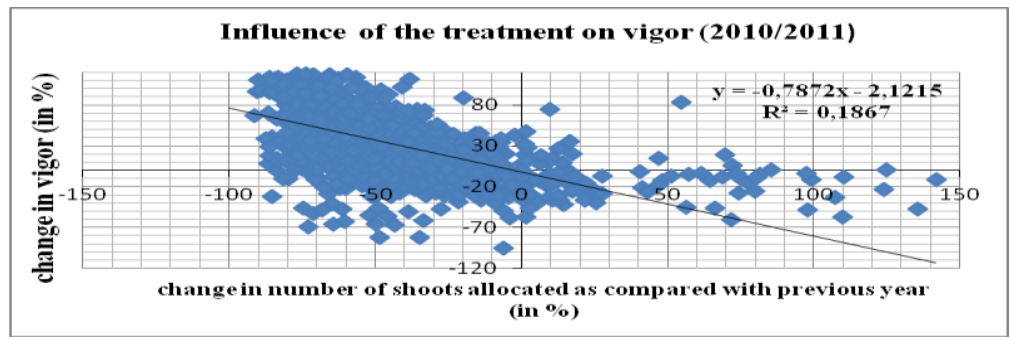

Figure2. Influence of the change of shoot number on the vigor (2010/2011)

The first treatment of the plot was done in 2011, the vines were pruned and the weight of their pruned wood was measured. The values obtained represented the vigor that the plant expressed during the 2010 growing season. After having repeated the operation in 2012 (to estimate vigor expressed in 2011), the change in vigor for each plant according to the change in number of shoots left was calculated in order to understand the response of the plant on the treatment (Figure 2).

Analyzing the effect of the treatment for the first year can observe a slight correlation $(\mathrm{r}=$ 0.43 ) and see more or less clear that more drastic was the decrease in the load compared to last year, more the vigor increased. About $6 \%$ of plants had an increase in vigor of more than $100 \%$.

Repeating the same operation in 2013 obtained the data to see the effect of the treatment on the 2012 growing patterns (Figure3).

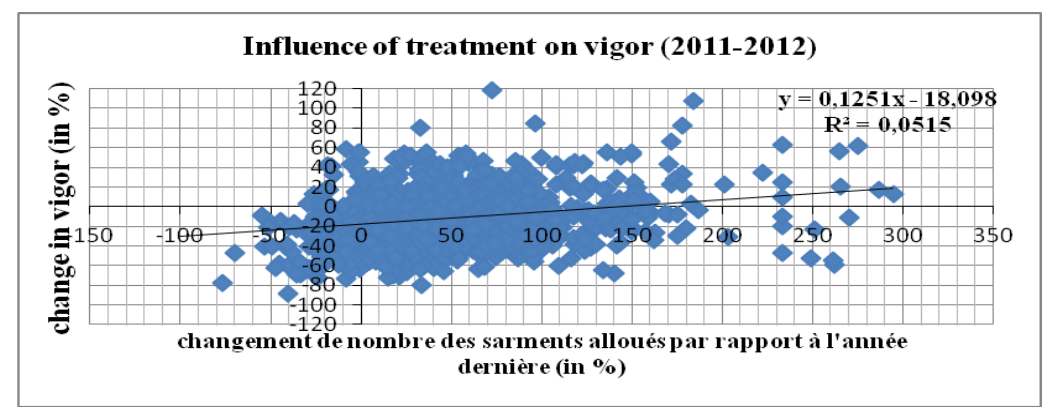

Figure3. Influence of the change of shoot number on the vigor (2011/2012) 
Analyzing the effect of the treatment for the second year (Figure 3), the correlation is too low $(r=0,23)$ to make any conclusion. Surprisingly, the two years of research show us two opposite trends. However, in practice this situation indicates that the plants in 2010 were unbalanced in terms of vigor/load and the treatment with technique Mas Martinet Assessoraments in winter 2011 distributed the vigor in a more appropriate way for each vine which resulted in a less pronounced effect from the treatment in 2012. Almost $70 \%$ of vines have reduced their vigor in 2012 in response to increased load within the limit of $145 \%$ load increase compared to last year.

To have a more clear idea on the effect of the treatment, it is interesting to have a look on the evolution of characteristics of groups formed in 2011. Figures 4, 5 and 6 show inter-annual differences.

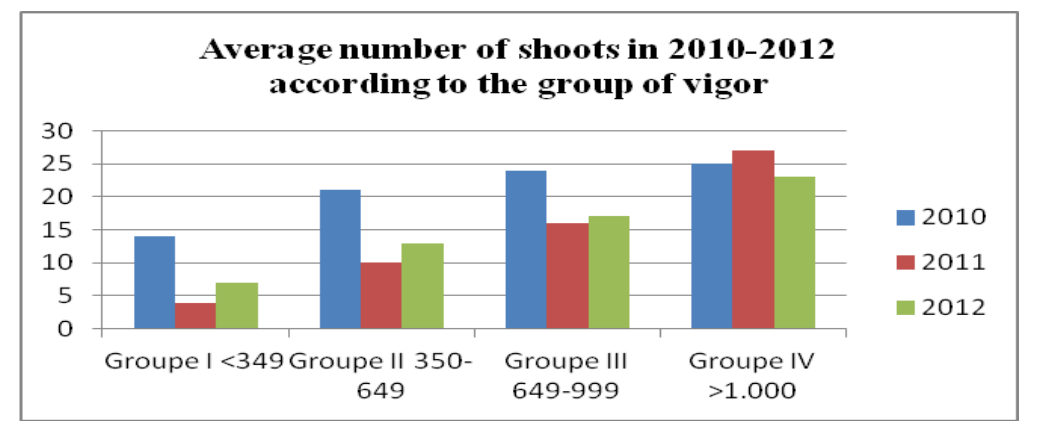

Figure4. Evolution of the average load per vine for groups formed in 2011 over 2010- 2012

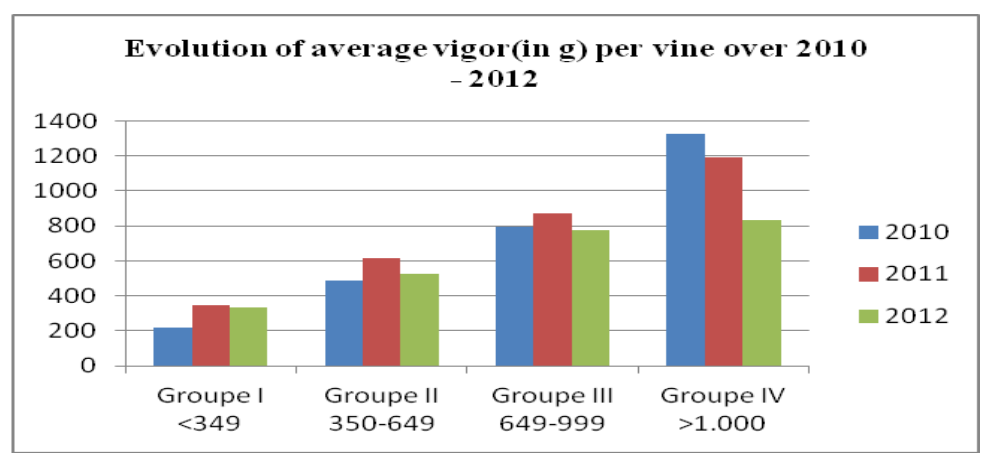

Figure5. Evolution of average vigor (in g) per vine for groups formed in 2011 over 2010 - 2011

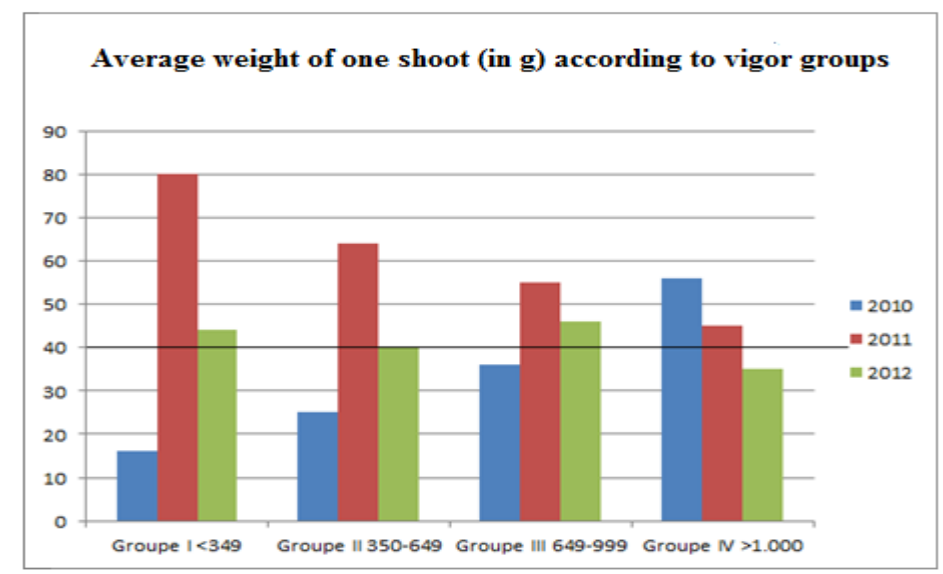

Figure 6. Average weight of one shoot (in g) according to vigor groups over 2010-2012

The results demonstrated on the three figures above show that the application of the technique Mas Martinet Assessoraments based on the distribution of vigor on an appropriate number of shoots has a significant effect on the vigor of the vine and the weight of each shoot. By the 2nd year after treatment it was observed that the average weight of a branch was close to $40 \mathrm{~g}$ regardless the vigor group. That is to say that in 2012 towards the end of growth all shoots achieved the average length of $132 \mathrm{~cm}$ (data not shown). 
Thus, we can conclude that by the 2 nd year after the application of the technique studied it is possible to level the variability of the growth of shoots within a plot and that the hypothesis $\mathrm{H} 1$ is true. In addition, Figures 6 and 7 show the veracity of the hypothesis H4 for all three vigor groups except Group IV in 2012.

\subsection{Shoot Length Evolution According to the Vigor Group In 2013}

To verify more in depth the veracity of the hypothesis H1, the measures of the length of shoots was carried out during growing season 2013. The result is compared with the data collected by Stein (2011).

On the Figure 7 we can be observe a different dynamic of growth for groups I and II, and III and IV. Indeed, in 2013 the final length of the shoots for all four groups is statistically significantly different $[\mathrm{F}(3,204)=4.144, \mathrm{p}=0.007]$. In 2011, according to Stein $(2011)$, the differences in length towards the end of growth were not statistically significant between the four groups $[\mathrm{F}(3,134)=0.49, \mathrm{p}=0.6886]$.

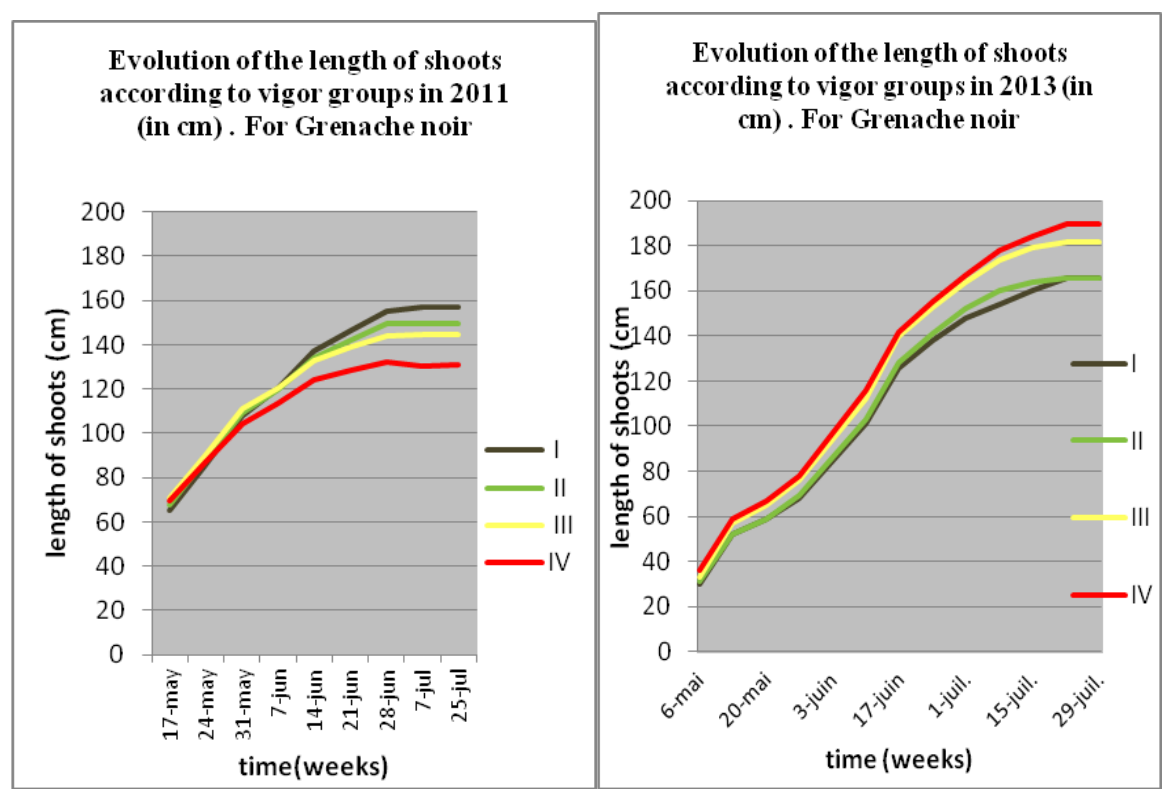

Figure 7. Shoot length evolution according to the vigor group in 2013compared to 2011

In practice, the differences in 2013 nevertheless seem to be not very significant. For example, a vine whose vigor was $300 \mathrm{~g}$ in 2013 grew six shoots of $166 \mathrm{~cm}$ on average and the other vine of 2000 g.grew 40 shoots of $190 \mathrm{~cm}$ on average. Following the logic of the principle of compensation of the plant (Rousseau, 2007), in the latest example the vinebeing loaded with 20 buds at the beginning of the growth would have produced 20 shoots of a considerably greater length than $190 \mathrm{~cm}$.

In 2013, the length of the shoots has far exceeded the expected range $(120 \mathrm{~cm})$. It was assumed that the increase in force was the result of a high rainfall as compared to previous years of the study (Table 1).A deeper study of the effect of climate on inter-annual variations of vigor must be conducted in order to better understand the response of the plant.

Table 1. Temperatures and rainfall during growing seasons 2011-2013

\begin{tabular}{|l|l|l|l|}
\hline Temp. $\left({ }^{\mathbf{0}} \mathbf{C}\right)$ & $\mathbf{2 0 1 1}$ & $\mathbf{2 0 1 2}$ & $\mathbf{2 0 1 3}$ \\
\hline April & 15,3 & 12,5 & 12,3 \\
\hline May & 18,1 & 17,9 & 14,2 \\
\hline June & 20,5 & 23,0 & 19,3 \\
\hline July & 22,9 & 23,2 & 25,6 \\
\hline August & 24,7 & 25,9 & 25,7 \\
\hline Average & 20,3 & 20,5 & 19,4 \\
\hline
\end{tabular}

\begin{tabular}{|l|l|l|l|}
\hline Rainfall (mm) & $\mathbf{2 0 1 1}$ & $\mathbf{2 0 1 2}$ & $\mathbf{2 0 1 3}$ \\
\hline April & 27 & 109 & 149 \\
\hline May & 56 & 6 & 43 \\
\hline June & 23 & 12 & 64 \\
\hline July & 2 & 15 & 8 \\
\hline August & 0 & 2 & 2 \\
\hline Total & $\mathbf{1 0 9}$ & $\mathbf{1 4 5}$ & $\mathbf{2 6 6}$ \\
\hline
\end{tabular}

The results of the chemical analysis of grapes and wine 
In the previous paragraph we have seen the effect of treatment on the growth of shoots originated from plants of different vigor and it was found that the within vineyard variability of shoot length has been considerably reduces after the treatment. However, the within variability of the quality of grapes and not of the length of shoots is a real challenge for viticulturist.

With the aim to verify whether the technique Mas Martinet Assessoraments is capable to homogenize the quality of grapes and of the wine originating from the vines of different vigor, a separated fermentations were set in 2011 (Table 2), 2012 (Table 3) and 2013.

Table 2 shows the results of analysis of qualitative parameters of wines from four vigor groups. The differences observed between the groups of vigor are consistent with the findings of Bramley and Hamilton (2007) and Cortell (2008) that suggest that the more structured wines come from low vigorous zones of the vineyard

Table 2. Results of chemical analysis of wines originating from four vigor groups in 2011 vintage.

\begin{tabular}{|l|l|l|l|l|l|}
\hline Wine & $\begin{array}{l}\text { AD } \\
(\% \text { vol })\end{array}$ & TA (g/L sulfuricacid) $)$ & pH & d280 & Tannins (g/L) \\
\hline Group I & $14,9 \pm 0,05$ & $3,2 \pm 0,01$ & $3,56 \pm 0,02$ & $45,2 \pm 0,09$ & $0,66 \pm 0,01$ \\
\hline Group II & $14,0 \pm 0,04$ & $3,5 \pm 0,02$ & $3,55 \pm 0,02$ & $39,3 \pm 0,07$ & $0,58 \pm 0,01$ \\
\hline Group III & $13,8 \pm 0,04$ & $3,3 \pm 0,01$ & $3,53 \pm 0,02$ & $38,2 \pm 0,07$ & $0,54 \pm 0,01$ \\
\hline Group IV & $13,2 \pm 0,04$ & $2,9 \pm 0,01$ & $3,61 \pm 0,03$ & $31,6 \pm 0,06$ & $0,39 \pm 0,01$ \\
\hline Bancal Gran & $14,0 \pm 0,04$ & $3,2 \pm 0,01$ & $3,56 \pm 0,02$ & $38,1 \pm 0,07$ & $0,54 \pm 0,01$ \\
\hline
\end{tabular}

In 2012 (Table 3) the composition of the wine has changed considerably and this time significant differences between groups were not identified except for d280 and TAV for Group I.

Table 3. Results of chemical analysis of wines from four vigor groups in 2012 vintage.

\begin{tabular}{|l|l|l|l|l|l|l|}
\hline Wine & $\begin{array}{l}\text { AD } \\
(\% \text { vol })\end{array}$ & TA $(\mathrm{g} / \mathrm{L}$ sulfuric acid $)$ & $\mathrm{pH}$ & $\mathrm{d} 280$ & Tannins $(\mathrm{g} / \mathrm{L})$ & $\mathrm{IC}$ \\
\hline Group I & $13,0 \pm 0,04$ & $3,0 \pm 0,01$ & $3,82 \pm 0,03$ & $40,0 \pm 0,06$ & $2,1 \pm 0,01$ & $0,57 \pm 0,01$ \\
\hline Group II & $12,7 \pm 0,01$ & $3,2 \pm 0,02$ & $3,78 \pm 0,03$ & $35,3 \pm 0,05$ & $1,9 \pm 0,01$ & $0,56 \pm 0,01$ \\
\hline Group III & $12,7 \pm 0,02$ & $3,1 \pm 0,02$ & $3,73 \pm 0,01$ & $35,1 \pm 0,05$ & $1,9 \pm 0,01$ & $0,59 \pm 0,02$ \\
\hline Group IV & $12,8 \pm 0,02$ & $3,1 \pm 0,01$ & $3,76 \pm 0,02$ & $34,3 \pm 0,04$ & $2,4 \pm 0,02$ & $0,53 \pm 0,01$ \\
\hline Bancal Gran & $12,8 \pm 0,03$ & $3,1 \pm 0,02$ & $3,77 \pm 0,02$ & $36,2 \pm 0,06$ & $2,1 \pm 0,02$ & $0,55 \pm 0,01$ \\
\hline
\end{tabular}

In order to verify if the differences between the wines studied were perceptible at sensory level, a formal tasting with a panel of certified tasters was organized and duo-trio tests together with the descriptive test were implemented.

Table 4. Duo-trio test results. Comparison between wines coming from different vigor groups.

\begin{tabular}{|l|l|l|l|}
\hline $\begin{array}{l}\text { Pares tested } \\
\text { between vigor groups }\end{array}$ & Number of taster & Correct answers & Risca \\
\hline G1 and G2 & 8 & 0 & $>0.9999$ \\
\hline G1 and G3 & 8 & 1 & 0,961 \\
\hline G1 and G4 & 8 & 2 & 0,8049 \\
\hline G2 and G4 & 8 & 6 & $\mathbf{0 . 0 1 9 7 *}$ \\
\hline G2 and G3 & 8 & 5 & 0,0879 \\
\hline G3 and G4 & 8 & 2 & 0,8049 \\
\hline
\end{tabular}

*Significance level - $95 \%$

As can be seen from the table, significant differences were found only between G2 and G4 wines. To understand the nature of these differences, a descriptive test was implemented. The test includes evaluation of 32 attributes describing the color, taste and aroma characteristics. The results of the test are shown in Figure 8. 
According to the official conclusion of the Research Center Vitec on descriptive test of samples G2 and G4, the differences between G2 and G4 were not found in any attribute except astringency at a low level of significance (>95\%). This corresponds to the results of unofficial blind tastings organized by us with winemakers, students and professionals of the wine market. The majority of the tasters could not distinguish samples and correlate their quality with the vigor. Taking into account the results of chemical analysis of wines from all four groups, official and unofficial tastings, we concluded that the $\mathrm{H} 2$ hypothesis stating that the vigor of vines treated with the technique Mas Martinet Assessoraments do not affect the quality of the production (for the second year in the study).

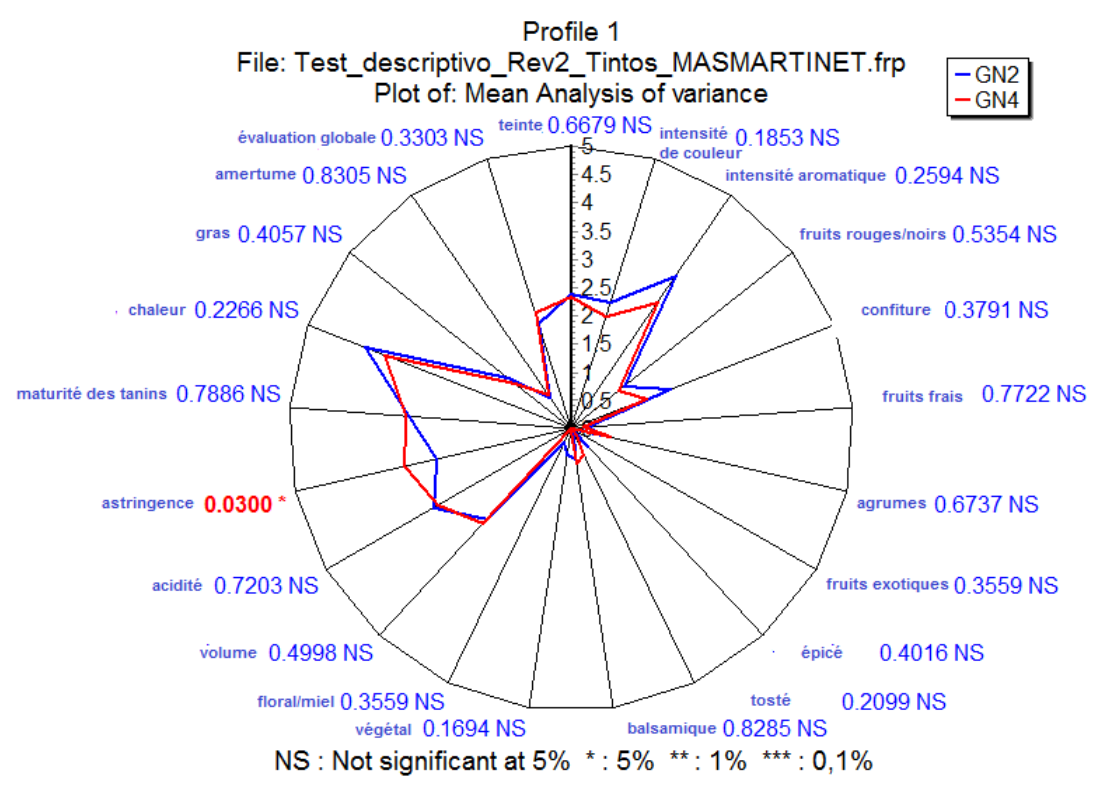

Figure8. Comparison of the results between $G 2$ and $G 4$ groups

\section{Conclusions}

Using the technique of vigor control developed by Mas Martinet Assessoraments, the within vineyard variability in terms of the growth of shoots, grape and wine quality was mastered by the second year of the study. This fact challenges the veracity of so far undoubted concept in viticulture that the raw material of best quality for premium wines comes from low vigor vines. If under normal conditions the quality of the grapes originating from vigorous areas in considered to be lower, we can deduce that in our study having achieved the quality performance of high vigorous vines comparable with that of plants of low vigor actually means an increase in quality of the entire production. Practically, the treatment studied in this work, is able to replace such management of within vineyard variability as dividing of the parcel on vigor zones and offers a possibility of improving the quality of raw material from vigorous vines. The use of the technique of vigor control can provide an economic advantage to the producers through both higher yields and better quality.

Because the method used in this study to achieve the balance of the plant in terms of production/ vigor is based on the weighing the pruned wood and allocation of the corresponding number of shoots for each plant individually, this technology may seem expensive and impractical in real production conditions. However, the adaptation of new trellising systems as "double tying " and "circle" (Perez, 2007) can provide an opportunity for effective management of the within vineyard variability without exceeding the amount of hours reserved for pruning operation. The development of the Precision Viticulture in the direction of designing new digital and geo-referenced equipment that would be able to inform the worker about the vigor of each plant could replace the time consuming operation of weighing the wood and help him to make the correct decision on the load to be left for each vine. 


\section{REFERENCES}

ARCHER E. et STRAUSS H.C., The Effect of Vine Spacing on the Vegetative and Reproductive Performance of Vitisvinifera L. (cv. Pinot noir),). S. Afr. J. Enol. Vitic., 1991, 12,70 -76.

ARCHER E. et STRAUSS H.C., The Effect of Vine Spacing on Some Physiological Aspects of Vitisvinifera L. (cv. Pinot noir), S. Afr. J. Enol. Vitic, 1990, 11, 76-87.

ARCHER, E.; HUNTER, J.J., Increased yield in wine grapes for specific production goals. [Enligne].In: Technical Guide for Wine Producer, Stellenbosch: Wineland. Disponible sur: http://www.wynboer.co.za/recentarticles/1003yield.php3. (Consulté le 28 avril 2013).

BARBEAU G. Influence du fonctionnement de la vigne sur la qualité du vin. [En ligne]. In : Techniloire. Disponible sur : http://www.techniloire.com/documents/124963587/article73.pdf . (Consulté le 2 juin 2013).

BARBEAU G. Mesure des variables de fonctionnement de la vigne. Le cours de Module «Terroirs viticoles européens », Master Vintage, 2012.

BRAMLEY, R.G.V. Smarter thinking on soil survey. Wine Industry Journal, 2003, 18, 88-94.

BRAMLEY R.G.V.Variation in vine vigor, grape yield and vineyard soils and topography as indicators of variation in the chemical composition of grapes, wine and wine sensory attributes. Australian Journal of Grape and Wine Research, 2011, 17, 2, p. 217-229

BRAMLEY R.G.V et HAMILTON R.P. Understanding variability in winegrape production systems. Within vineyard variation in yield over several vintages. Australian Journal of Grape and Wine Research, 2004, 10, p. 32-45.

BRAMLEY, R.G.V., Understanding variability in winegrape productionsystems.2. Within vineyard variation in quality over several vintages. Australian Journal of Grape and Wine Research, 2005, 11, p. 33-42.

BRAMLEY, R.G.V., Selective harvesting is a feasible and profitable strategy even when grape and wine production is geared towards large fermentation volumes. Australian Journal of Grape and Wine Research, 2011, 17, p. 298-305.

BRAMLEY, R. G. V., \& Hamilton, R. P. Terroir and precision viticulture: are they compatible? Journal International des Sciences de la Vigne et du Vin, 2007, 41(1), 1-8.

BYRNE M. ET HOWELL G., Initial response of Baco Noir grapevines to pruning severity, sucker removal and weed control. Am. J. Enol. Vitic.,1978, 29,3, p. 192-198.

CARMONA M. J., A molecular genetic perspective of reproductive development in grapevine. Abstract. Journal of Experimental Botany, 2008, 59,15, p. 4288, 2008.

CORTELL, J.M., HALBLIEB M., Gallagher A.V et al. Influence of vine vigor on grape (Vitisvinifera L. Cv. Pinot Noir) anthocyanins. 1. Anthocyanin concentration and composition in fruit. J. Agric. Food Chem. 2007, 55 (16), p. 6575-6584.

CORTELL, J. M., Sivertsen H. K., Kennedy J.A. et al. Influence of vine vigor on Pinot noir fruit composition, wine chemical analysis, and wine sensory attributes. Am. J. Enol. Vitic., 2008, 59 (1), p. 1-10.

CLOETE H., ARCHER E., NOVELLO V. et al., Shoot heterogeneity effects on Shiraz/Richter99 grapevines. III Leaf chlorophyll content. South African Journal of Enology and Viticulture, 2008, 29 ,1, p. 9-12.

DIXON R.A. The influence of vine vigour and crop load on Sauvignon blanc vine growth and fruitcompositioninMarlborough,NewZealand.[Enligne].Thèsedemaster.LincolnUniversity.2009. Disponiblesurhttp://researcharchive.lincoln.ac.nz/dspace/bitstream/10182/2649/3/Dixon_MASc. pdf. (Consultéle 25 mars 2013).

DOBROWSKI S.Z. Grapevine dormant pruning weight prediction using remotely sensed data, Australian Journal of Grape and Wine Research, 2003, 9(3). p. 177-182.

DUNN G., MARTIN S., A functional association in Vitisvinifera L. cv. Cabernet Sauvignon between the extent of primary branching and the number of flowers formed per inflorescence. Australian Journal of Grape and Wine Research, 2007,13,2, p. 95-100. 
FIDELIBUS M. et VASQUEZ S., Using Gibberellic Acid to Reduce Cluster Compactness in Grapes. [Enligne].In:University of California. Disponible sur: http://www.extension.org/pages/31608/ using-gibberellic-acid-to-reduce-cluster-compactness-in-grapes. (Consulté le 4 juillet 2013).

FREEMAN B, Effects of irrigation and pruning of Shiraz grapevines on subsequent red wine pigments. Am. J. Enol. Vitic., 1983, 34,1, p. 23-26.

GALET P., Précis de viticulture. Ed. Dehan, Montpellier, 1993, 582 p.

GARINE P. Densité de plantation et conduite du feuillage. [En ligne]. In : Chambre d'agriculture du Vaucluse. Disponible sur: www.institut-rhodanien.com/download/780. (Consulté le 13 juin 2013).

HATEM M., Influence de la vigueur et du system de conduite de la vigne (vitisvinifera 1.) sur sa structure géométrique et son microclimat lumineux en tant que facteurs de la qualite de la vendange. These de Doctorat. Montpellier: ENSA, 1998.

HED B. Relationship Between Cluster Compactness and Bunch Rot in Vignoles Grapes, Plant Disease, 2009, 93, p.1195-1201.

IRIMIA L., TARDEA C., - The exposable leaf area and the leaf index, which characterize the grapevine training systems in the Avereşti wine-growing centre, Huşi vineyard. Rev. CercetăriAgronomiceîn Moldova, 2006, 3,127), p. 41-46.

KLIEWER W.M. et DOKOOZLIAN N.K., Leaf area/crop weight ratios of grapevines: influence on fruit composition and wine quality. American Journal of Enology and Viticulture, 2005, 56, p. 170-181.

LANDOLT, J. Effects of pruning level and canopy management practices on berry maturation rate and harvest parameters of Syrah wine grapes. Thèse de Master. San Luis Obispo: CaliforniaPolytechnic State University, 2011, 61 p.

MARGUERIT E. et al., La télédétection à haute résolution pour spatialiser les variations intraparcellaires de la vigueur de la vigne. VIe Congrès International des terroirs viticoles, 2006.

MILES G., Impact of Soil Variation on a Vineyard Water Balance. [En ligne]. Disponible sur: http://www.uwa.edu.au/_data/assets/pdf_file/0006/1637331/Miles_2005.pdf. (Consulté le 5 juin 2013).

MURISIER F. ET ZUFFEREY V., Optimalisation de la charge en rameaux de la vigne: essai sur Chasselas. Revue Suisse Vitic. Arboric.Hortic., 1996, 28, 131-137.

OLLAT N., Influence de systèmes de conduite. [En ligne]. In : UREFV-INRA. Disponible sur : http://www.vignevin-sudouest.com/publications/itvcolloque/documents/COLLOQUE_Systemesconduite_OLLAT.pdf. (Consulté le 11 juin 2013).

PEREZ J.L. Manuel of techniques for sustainablemountain viticulture. [En ligne]. In: Mas Martinet Asssessoraments, Espagne. Site disponible sur: http://www.masmartinetass.com/eng/item/ART00013.html. (Page consulté le 15 mars 2013).

RIBEREAU-GAYON P., STONESTREET E. Le dosage des anthocyanes dans les vins rouges. Bull. Soc. Chim, 1965, 9, 2649-2652.

RIBEREAU-GAYON P.. Dosage des composés phénoliques totaux des vins rouges. Chim. Anal., 1970, 52, 627-631.

REYNOLDS A., WARDLE D. et DEVER M., Shoot density effects on Riesling grapevines: interactions with cordon age. Am. J. Enol. Vitic., 1994, 45,4, p. 435-443.

ROUSSEAU J., DUPIN S., Acevedo-Opazo C., Tisseyre B. \& Ojeda H.,. L'imagerie aérienne application à la caractérisation des potentiels viticoles et oenologiques. Bulletin de l'Organisation Internationale de la Vigne et du Vin. 2008, 81, 507-517.

ROUSSEAU J., CARBONNEAU A. La taille minimale, une voie pour la maîtrise des coûts de production? Revue des œnologues et des techniques vitivinicoles et œnologiques, 2007, 34, 122 , p. $39-42$

SHAVRUKOV Y., DRY I., Inflorescence and bunch architecture development in Vitisvinifera L., Australian Journal of Grape and Wine Research 2004, 10, 2, p. 116-124

SMART R., Canopy management. Le cours de Module «Viticulture », Master Vintage, 2012. 
SMART, R., Principles of grapevine canopy microclimate manipulation with implications for yield and quality. American Journal of Enology and Viticulture, 1985, 36,3, p. 230 - 239.

SMART, R., Shoot spacing and canopy light microclimate. American Journal of Enology and Viticulture, 1988, 39, 4, p. 325 - 333.

STEIN, J.Vine vigour and within-vineyard variability: The effect of corrective pruning and shoot spatial distribution on vine vigour and shoot length evolution of Vitisvinifera L. cv. Grenache noir (normal) and Grenache peluda/R110 in Priorat, Catalunya, Spain. Thèse de Master. Angers : ESA-Group, 2011, 75 p.

TISSEYRE B. et RUDNICKI V., La variabilité intra-parcellaire support de la viticulture de Précision.[Enligne].In: ICV. Disponible sur: Lhttp://www.icv.fr/documents/Bibliotheque/ Biblio_Articles/Articles_Viti/Variabilite_intraparcellaire_Vinitech08.pdf. (Consulté le 4 juin 2013).

WEAVER, R.J., KASIMATIS, A.N. et MCCUNE, SB., Studies with gibberellin on wine grapes to decrease bunch rot. Am. J. Enol. Vitic, 1962 13, 78-82.

WESTOVER F., Dormant Grapevine Pruning. [Enligne]. In : Texas winegrape network. Disponible sur : http://winegrapes.tamu.edu/grow/pruning.html. (Consulté le 2 juin 2013).

WINKLER A., COOK, J., KLIEWER, W. et al, General Viticulture, 1974, University of California Press, Berkeley.

WOLF, T.K. et POLING E.B., The Mid-Atlantic Winegrape Grower's Guide. [En ligne]. In: North Carolina Cooperative extension service. Disponible sur:http://cals.ncsu.edu/hort_sci/extension/ wine_grape.php. (Consulté le 2 juin 2013).

ZABADAL T., DITTMER T., Quantitative measurement of cluster compactness in several table grape cultivars. HortScience, 1992, 27, 6, p. 599-600. 